Research Article

\title{
The Protective Role of Hyaluronic Acid in Cr(VI)-Induced Oxidative Damage in Corneal Epithelial Cells
}

\author{
Wei Wu, ${ }^{1}$ Hua Jiang, ${ }^{1}$ Xinnian Guo, ${ }^{2}$ Yu Wang, ${ }^{2}$ Shibo Ying, ${ }^{2}$ Lingfang Feng, ${ }^{2}$ Tao Li, ${ }^{2}$ \\ Hailing Xia, ${ }^{2}$ Yixiao Zhang, ${ }^{2}$ Riping Chen, ${ }^{2}$ Tianhui Chen, ${ }^{2}$ and Jianlin Lou ${ }^{2}$ \\ ${ }^{1}$ The Second Affiliated Hospital of Zhejiang University School of Medicine, Hangzhou, Zhejiang 310009, China \\ ${ }^{2}$ Institute of Occupational Disease, Zhejiang Academy of Medical Sciences, Hangzhou, Zhejiang 310013, China \\ Correspondence should be addressed to Jianlin Lou; jianlinlou@163.com
}

Received 20 November 2016; Accepted 26 January 2017; Published 27 March 2017

Academic Editor: Edward Manche

Copyright ( 2017 Wei Wu et al. This is an open access article distributed under the Creative Commons Attribution License, which permits unrestricted use, distribution, and reproduction in any medium, provided the original work is properly cited.

$\mathrm{Cr}(\mathrm{VI})$ exposure could produce kinds of intermediates and reactive oxygen species, both of which were related to DNA damage. Hyaluronan (HA) has impressive biological functions and was reported to protect corneal epithelial cells against oxidative damage induced by ultraviolet $\mathrm{B}$, benzalkonium chloride, and sodium lauryl sulfate. So the aim of our study was to investigate HA protection on human corneal epithelial (HCE) cells against $\mathrm{Cr}(\mathrm{VI})$-induced toxic effects. The HCE cell lines were exposed to different concentrations of $\mathrm{K}_{2} \mathrm{Cr}_{2} \mathrm{O}_{7}(1.875,3.75,7.5,15.0$, and $30 \mu \mathrm{M})$ or a combination of $\mathrm{K}_{2} \mathrm{Cr}_{2} \mathrm{O}_{7}$ and $0.2 \% \mathrm{HA}$ and incubated with different times (15 min, $30 \mathrm{~min}$, and $60 \mathrm{~min})$. Our data showed that $\mathrm{Cr}(\mathrm{VI})$ exposure could cause decreased cell viability, increased DNA damage, and ROS generation to the HCE cell lines. But incubation of HA increased HCE cell survival rates and decreased DNA damage and ROS generation induced by $\mathrm{Cr}(\mathrm{VI})$ in a dose- and time-dependent manner. We report for the first time that HA can protect $\mathrm{HCE}$ cells against the toxicity of $\mathrm{Cr}(\mathrm{VI})$, indicating that it will be a promising therapeutic agent to corneal injuries caused by $\mathrm{Cr}(\mathrm{VI})$.

\section{Introduction}

Chromium (Cr) exists in many states, and the forms of hexavalent chromium [Cr(VI)] and trivalent chromium [Cr(III)] are found commonly in the environment. $\mathrm{Cr}(\mathrm{VI})$ is considered more toxic than $\mathrm{Cr}$ (III) as it can readily enter cellular membranes via nonspecific anion carriers. $\mathrm{Cr}(\mathrm{VI})$ is widely used in chemical industries such as electroplating, welding, dyes, paint pigments, leather tanning, and so forth. Many studies have reported that soluble hexavalent chromium is a powerful epithelial irritant with oxidizing and strong acid properties, leading to respiratory, dermatic, and ocular irritations, such as cough, dyspnea, sneezing, contact dermatitis, skin ulcers, eye redness, tearing, photophobia, and vision blurring [1-7].

It is widely accepted that cellular reduction of $\mathrm{Cr}(\mathrm{VI})$ is an activation process that generates variable intermediates $[\mathrm{Cr}(\mathrm{V})$ and $\mathrm{Cr}(\mathrm{IV})]$ and reactive oxygen species (ROS) [8-11]. The intermediates formed during cellular $\mathrm{Cr}(\mathrm{VI})$ reduction are able to cause hydroxyl radical generation that is responsible for DNA strand breaks [12]. Meanwhile, the comet assay has been found to be a very sensitive and reliable method for measuring DNA damage. ROS are generated as a by-product of normal mitochondrial activity and scavenged by an antioxidant system in aerobic cells. The balance between oxidants and antioxidants may be broken by overproduced ROS, which can cause oxidative stress such as lipid peroxidation (LPO), decreased cell viability, increased DNA damage, and apoptosis [13]. Oxidative stress can then play a major role in inducing genetic and epigenetic alterations to organisms and is associated with carcinogenesis $[8,9,14-16]$. Both in vivo and in vitro studies have reported that $\mathrm{Cr}(\mathrm{VI})$ exposure could induce oxidative stress, which is one of the mechanisms of toxicity of $\mathrm{Cr}(\mathrm{VI})$. Nevertheless, there are very limited data reporting the toxic effects and mechanisms of $\mathrm{Cr}(\mathrm{VI})$ on the eye.

The corneal epithelial cell is located in the outermost layer of the eyeball and is susceptible to oxidative damage. 
In the chemical manufacturing associated with chromium, occupational exposure increases the chance of damage on ocular surfaces such as the cornea. The cytotoxicity of ocular tissues induced by chromium was investigated rarely. Asmatullah and Shakoori studied the effect of hexavalent $\mathrm{Cr}$ on the development of chicken eye and found that in treated groups, the eye was defective with the undifferentiated cornea, lens, and retina [17]. Chromium picolinate could induce several hazards to the cornea and lens including a significant decrease in SOD, GSH, and $\mathrm{Na}^{+}$- and $\mathrm{K}^{+}$-ATPase levels; a significant increase in MDA level; and severe morphological and histological changes [13]. Apel et al. reported that cobalt-chromium toxicity could cause inner retinal dysfunction [18]. Hexavalent chromium-caused ocular trauma especially cornea injury has been reported in China $[6,7]$, while the toxicity and its mechanism are not very clear.

Hyaluronic acid (hyaluronan, HA) is a linear nonsulfated polysaccharide chain composed of $\beta$-1,4-glucuronic acid alternated with $\beta-1,3-\mathrm{N}$-acetylglucosamine [19], which belongs to the glycosaminoglycan family. Hyaluronan, a ubiquitous extracellular matrix ingredient, exists in many parts of the human body such as the cornea, the vitreous body of the eye, joints, and skin. In clinical practice of ophthalmology, HA has impressive biological functions and is used in eye drops for dry eye syndrome to increase tear film stability and reduce subjective symptoms, such as ocular irritation and burning [20]. Hyaluronic acid (HA) is considered a remarkable antioxidant and ROS scavenger [21-23]. It was reported that high-molecular weight hyaluronan (HMW$\mathrm{HA}, 1000 \mathrm{kDa}$ ) could protect corneal epithelial cells against oxidative damage induced by ultraviolet B [24, 25], benzalkonium chloride [22], sodium lauryl sulfate [26], and so on. Our study was performed to demonstrate whether HMW$\mathrm{HA}$ is protective towards $\mathrm{Cr}(\mathrm{VI})$-induced oxidative damage to corneal epithelial cells.

\section{Materials and Methods}

2.1. Cell Culture and Treatment. The human corneal epithelial cell line was provided by New York University. The cells were cultured in DMEM/F12 (Gibco, Grand Island, NY) supplemented with $10 \%$ fetal bovine serum (HyClone, USA), $5 \mu \mathrm{g} / \mathrm{ml}$ insulin (Gibco), $0.1 \mu \mathrm{g} / \mathrm{ml}$ cholera toxin, $5 \mathrm{ng} / \mathrm{ml}$ human epidermal growth factor (Gibco), and $40 \mu \mathrm{g} / \mathrm{ml}$ gentamicin at $37^{\circ} \mathrm{C}$ in a fully humidified atmosphere with $5 \%$ $\mathrm{CO}_{2}$. The cells were subcultured every 2-3 days. Cells were exposed to potassium dichromate $\left(\mathrm{K}_{2} \mathrm{Cr}_{2} \mathrm{O}_{7}\right.$, Sigma, USA) at concentrations of $1.875,3.75,7.5,15.0$, and $30 \mu \mathrm{M}$ or exposed to a combination of $\mathrm{K}_{2} \mathrm{Cr}_{2} \mathrm{O}_{7}$ and $0.2 \% \mathrm{HA}$ (1000 kDa; Freda Biopharm Co. Ltd., Shandong, China) for $15 \mathrm{~min}, 30 \mathrm{~min}$, and $60 \mathrm{~min}$.

2.2. CCK-8 Assay. Cell viability was assessed by Cell Counting Kit-8 (CCK-8) (Dojindo Laboratories, Kumamoto, Japan), according to the description of our previous study [27]. Briefly, three wells were prepared for each sample in a 96-well plate. After treatment, $10 \mu \mathrm{l}$ of CCK-8 solution was added to each well and incubated at $37^{\circ} \mathrm{C}$ for 1 hour, and then, the optical density (OD) value for each well was measured at a wavelength of $450 \mathrm{~nm}$ on a microplate reader (Tecan Sunrise, Switzerland). The cell viability was calculated as follows:

Cell viability $(\%)=\frac{\mathrm{OD}(\text { experiment })-\mathrm{OD}(\text { blank })}{\mathrm{OD}(\text { control })-\mathrm{OD}(\text { blank })} \times 100$

where OD (experiment) is the absorbance of a well with treated cells and CCK-8, OD (blank) is the absorbance of a well with medium and CCK- 8 but without cells, and OD (control) is the absorbance of a well with untreated cells and CCK-8.

2.3. Comet Assay. The alkaline comet assay was performed according to the description by Singh et al. [28]. The viability of cells was first assessed with the trypan blue dye exclusion test. Then, the cells were embedded in $0.65 \%$ low-melting point agarose at a final concentration of $10^{4}$ cells $/ \mathrm{ml} ; 75 \mu \mathrm{l}$ of this cellular suspension was then spread onto a frosted slide that had been previously covered with $100 \mu \mathrm{l}$ of $1 \%$ normal-melting point agarose (as the first layer). The slides were immersed in freshly prepared lysis solution (1\% sodium sarcosinate, $2.5 \mathrm{M} \mathrm{NaCl}, 100 \mathrm{mM} \mathrm{Na}{ }_{2}$ EDTA, $10 \mathrm{mM}$ Tris$\mathrm{HCl} \mathrm{pH} \mathrm{10,1 \%} \mathrm{Triton} \mathrm{X-100,} \mathrm{and} \mathrm{10 \%} \mathrm{DMSO)} \mathrm{at} 4^{\circ} \mathrm{C}$ for $1 \mathrm{~h}$. Then, the slides were placed in a horizontal electrophoresis unit covered with fresh buffer ( $1 \mathrm{mM} \mathrm{Na}{ }_{2}$ EDTA, $300 \mathrm{mM}$ $\mathrm{NaOH}$ pH 13) for $20 \mathrm{~min}$. Electrophoresis was performed for $20 \mathrm{~min}$ at about $1.5 \mathrm{~V} / \mathrm{cm}$ and $300 \mathrm{~mA}$. Subsequently, the slides were washed gently 2 times in neutralization buffer (0.4 M Tris-HCl, pH 7.5). Each slide was stained with $40 \mu \mathrm{l}$ of ethidium bromide $(20 \mu \mathrm{g} / \mathrm{ml})$. All the above steps were conducted under yellow light $(580 \mathrm{~nm})$ to avoid additional DNA damage.

Observations were made as previously described [27], using a fluorescence microscope (Olympus, BX51) equipped with a $530 \mathrm{~nm}$ excitation filter, a $590 \mathrm{~nm}$ emission filter, and a camera (Olympus, DP50). Fifty cells from each of the two replicate slides per sample were selected for data analysis, and the CASP software was used to analyze the comets and the percentage of DNA in the comet tail was calculated [29].

2.4. ROS Detection. The ROS generation in human B lymphoblastoid cells was measured with the $2^{\prime}, 7^{\prime}$-dichlorodihydrofluorescin diacetate (DCFH-DA) method [30] on the basis of the ROS-dependent oxidation of DCFH-DA to $2^{\prime}, 7^{\prime}$-dichlorofluorescin (DCF). After exposure to metal compounds, cells were washed twice and resuspended with PBS $\left(1 \times 10^{6}\right.$ cells $\left./ \mathrm{ml}\right)$. The suspended cells were incubated with DCFH-DA $(5 \mu \mathrm{M})$ at $37^{\circ} \mathrm{C}$ for 30 minutes. The fluorescence intensity of each sample was detected by a multimode plate reader at an excitation wavelength of $485 \mathrm{~nm}$ and an emission wavelength of $528 \mathrm{~nm}$. Finally, the ratio between the fluorescence intensity of each treated sample over negative controls was calculated.

\section{Results}

3.1. Cell Survival. As shown in Figure 1, the cell survival rates of human corneal epithelial cells exposed to $\mathrm{K}_{2} \mathrm{Cr}_{2} \mathrm{O}_{7}$ alone decreased significantly $(p<0.01)$ at the concentrations of 


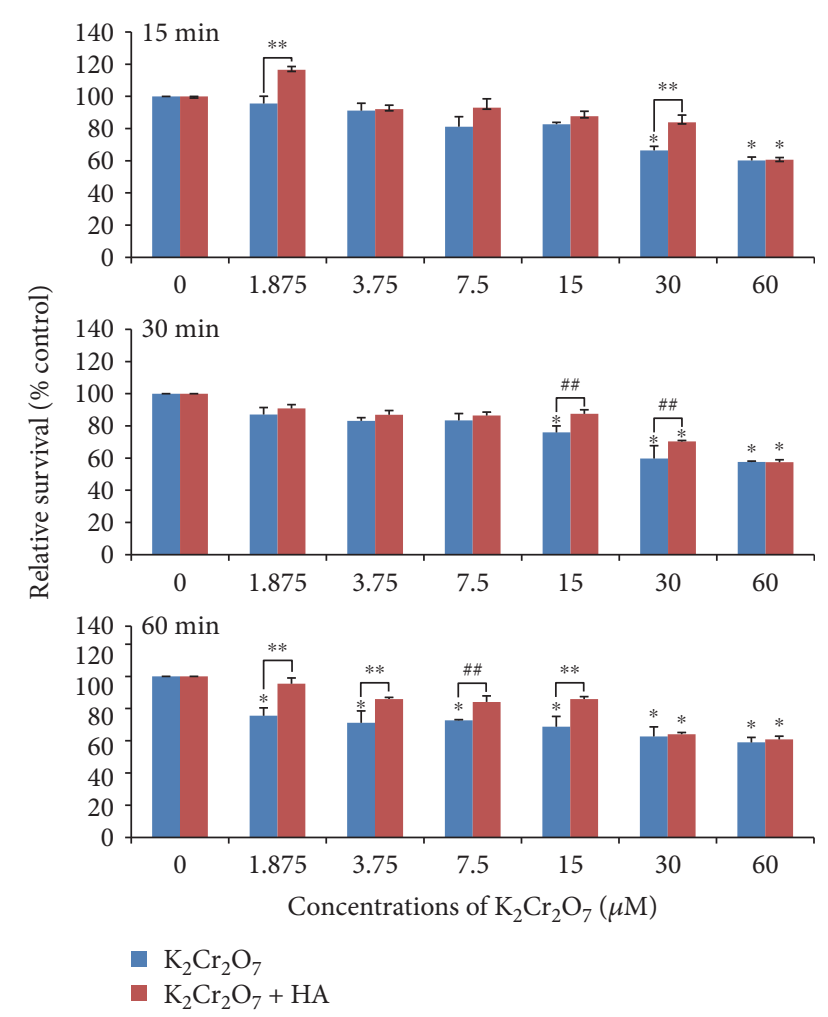

Figure 1: The effects of $\mathrm{Cr}(\mathrm{VI})$ or a combination of $\mathrm{Cr}(\mathrm{VI})$ and $\mathrm{HA}$ on the survival rates of HCE cells. ${ }^{*} p<0.01$, compared with the control. ${ }^{* *} p<0.01,{ }^{\# \#} p<0.05$, compared with the $\mathrm{K}_{2} \mathrm{Cr}_{2} \mathrm{O}_{7}$ group.

30-60 $\mu \mathrm{M}$ for the $15 \mathrm{~min}$ exposure group, $15-60 \mu \mathrm{M}$ for the $30 \mathrm{~min}$ exposure group, and $1.875-60 \mu \mathrm{M}$ for the $60 \mathrm{~min}$ exposure group, respectively. However, a significant $(p<0.01)$ decrease in relative cell survival rates of cells treated with a combination of $\mathrm{K}_{2} \mathrm{Cr}_{2} \mathrm{O}_{7}$ and $0.2 \% \mathrm{HA}$ was only observed at the concentrations of $30-60 \mu \mathrm{M}$, regardless of the exposure time. Moreover, $30 \mathrm{~min}$ preincubation of $0.2 \% \mathrm{HA}$ could significantly $(p<0.01)$ enhance the relative cell survival rates of cells treated with $\mathrm{K}_{2} \mathrm{Cr}_{2} \mathrm{O}_{7}$ at the concentrations of $1.875 \mu \mathrm{M}$ or $30 \mu \mathrm{M}$ for the $15 \mathrm{~min}$ exposure group, $15-30 \mu \mathrm{M}$ for the $30 \mathrm{~min}$ exposure group, and $1.875-15 \mu \mathrm{M}$ for the 60 min exposure group, respectively.

3.2. DNA Damage. Figure 2 shows the results of DNA damage. A significant $(p<0.01)$ increase in DNA damage was induced by $\mathrm{K}_{2} \mathrm{Cr}_{2} \mathrm{O}_{7}$ at the concentrations of $7.5-30 \mu \mathrm{M}$ in all the three exposure groups ( $15 \mathrm{~min}, 30 \mathrm{~min}$, and $60 \mathrm{~min}$ ). But $\mathrm{K}_{2} \mathrm{Cr}_{2} \mathrm{O}_{7}$ combined with $0.2 \%$ HA could only cause DNA damage ( $p<0.01$ compared to the control group) at the concentration of $30 \mu \mathrm{M}$ in the $15 \mathrm{~min}$ exposure group and at the concentrations of $15-30 \mu \mathrm{M}$ in the $30 \mathrm{~min}$ and $60 \mathrm{~min}$ exposure groups. Furthermore, $30 \mathrm{~min}$ preincubation of $0.2 \%$ HA could significantly $(p<0.05$ and $p<0.01)$ decrease DNA damage induced by $\mathrm{K}_{2} \mathrm{Cr}_{2} \mathrm{O}_{7}$ at the concentrations of $7.5 \mu \mathrm{M}$ and $15 \mu \mathrm{M}$ in all the three exposure groups (15 $\mathrm{min}, 30 \mathrm{~min}$, and $60 \mathrm{~min}$ ).

3.3. ROS Production. The results of ROS generation are shown in Figure 3. A dose- and time-dependent increase of

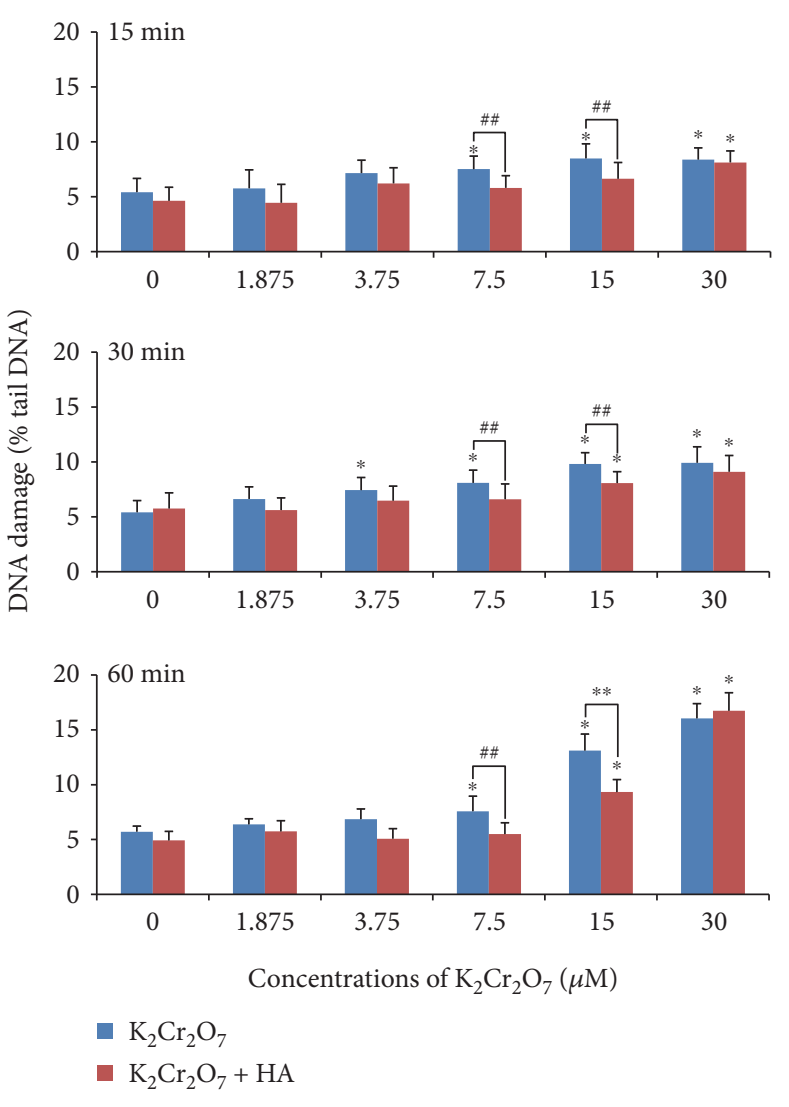

FIgURE 2: DNA damage induced by $\mathrm{Cr}(\mathrm{VI})$ or a combination of $\mathrm{Cr}(\mathrm{VI})$ and HA using the comet assay. ${ }^{*} p<0.01$, compared with the control. ${ }^{* *} p<0.01,{ }^{\# \#} p<0.05$, compared with the $\mathrm{K}_{2} \mathrm{Cr}_{2} \mathrm{O}_{7}$ group.

ROS levels was observed in cells treated with $\mathrm{K}_{2} \mathrm{Cr}_{2} \mathrm{O}_{7}$ alone, especially at the concentrations of $15-30 \mu \mathrm{M}, 7.5-30 \mu \mathrm{M}$, and $3.75-30 \mu \mathrm{M}$ in the $15 \mathrm{~min}, 30 \mathrm{~min}$, and $60 \mathrm{~min}$ exposure groups $(p<0.01)$, respectively. Preincubation of $0.2 \% \mathrm{HA}$ could significantly weaken the effects of $\mathrm{K}_{2} \mathrm{Cr}_{2} \mathrm{O}_{7}$ on ROS generation, and statistically significant $(p<0.01)$ difference of ROS production was observed at the concentrations of $15-30 \mu \mathrm{M}, 7.5-30 \mu \mathrm{M}$, and $3.75 \mu \mathrm{M}$ in the $15 \mathrm{~min}, 30 \mathrm{~min}$, and $60 \mathrm{~min}$ exposure groups, respectively.

\section{Discussion}

Most of the previous studies on hexavalent chromium focused on its carcinogenic effects, and various kinds of cell lines related to the respiratory system were used in in vitro studies. However, the toxic effects of hexavalent chromium on ocular surface cells were rarely investigated. Actually, workers occupationally exposed to hexavalent chromium also have many chances of exposing their ocular surface to this kind of chemicals and thus suffer damage to their ocular surface cells. Such cases have been reported in Chinese literatures. What is more, the epithelial corneal cells located on the most external cellular layers of the ocular surface are the first line to encounter environmental insults and play an important role in protecting the inner ocular tissues. Therefore, the present study investigated the cytotoxic 

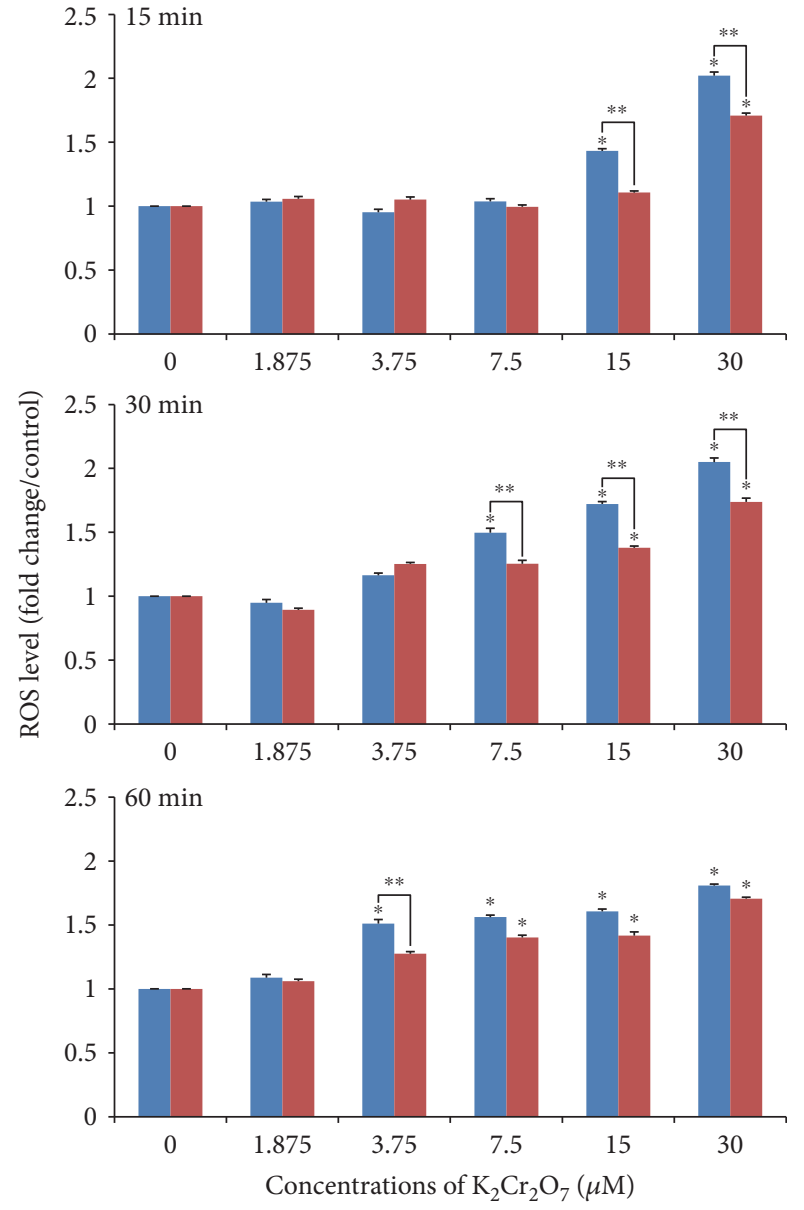

- $\mathrm{K}_{2} \mathrm{Cr}_{2} \mathrm{O}_{7}$

- $\mathrm{K}_{2} \mathrm{Cr}_{2} \mathrm{O}_{7}+\mathrm{HA}$

Figure 3: $\mathrm{Cr}(\mathrm{VI})$ or a combination of $\mathrm{Cr}(\mathrm{VI})$ and HA treatment induced ROS production in HCE cells. ${ }^{*} p<0.01$, compared with the control. ${ }^{* *} p<0.01$, compared with the $\mathrm{K}_{2} \mathrm{Cr}_{2} \mathrm{O}_{7}$ group.

effects, DNA damage, and ROS generation induced by hexavalent chromium in a human corneal epithelial cell line. Furthermore, the protective role of hyaluronic acid against toxic effects induced by hexavalent chromium was also studied.

The alkaline comet assay is a sensitive method for direct visualization of DNA strand breakage at the level of single cells. DNA damages have been reported in many $\mathrm{Cr}(\mathrm{VI})$ exposure studies [31]. DNA strand breaks, which belong to one of these DNA damages, have been reported in various kinds of cells using the comet assay [32-36]. And it is recognized that DNA strand break is caused by the reduction of $\mathrm{Cr}(\mathrm{VI})$ to lower oxidation states instead of $\mathrm{Cr}(\mathrm{VI})$ [12]. Our results show a clear concentrationand time-related increase in DNA damage by $\mathrm{Cr}(\mathrm{VI})$, which were consistent with the previous study conducted in human B lymphocytoid cells by Lou et al. [36]. The mechanism of DNA damage induced by $\mathrm{Cr}(\mathrm{VI})$ may be partially attributed to the production of ROS.

Our results indicated that $\mathrm{K}_{2} \mathrm{Cr}_{2} \mathrm{O}_{7}$ could induce ROS in human corneal epithelial cells even after $15 \mathrm{~min}$ exposure and the ROS levels increased after $\mathrm{K}_{2} \mathrm{Cr}_{2} \mathrm{O}_{7}$ treatment in a time- and dose-dependent manner. Similar results were reported in previous studies conducted in human liver carcinoma (HepG2) cells [35] or in human B lymphoblastoid cells [36], but the exposure time of $\mathrm{Cr}(\mathrm{VI})$ in these studies was usually longer than $1 \mathrm{~h}$. More recently, Lee et al. [37] demonstrated that a significant increase in ROS level was observed in $\mathrm{HaCaT}$ cells exposed to $15 \mu \mathrm{M}$ of $\mathrm{Cr}(\mathrm{VI})$ for less than $1 \mathrm{~h}$, and it was in accordance with our results. Overproduced ROS, which include superoxide, hydrogen peroxide, hydroxyl radicals, and so on, can attack important biomolecules such as DNA, proteins, and lipids [38]. For example, Atilano et al. found that hydrogen peroxide could cause mitochondrial DNA damage in corneal epithelial cells [39]. Therefore, we speculated that the balance between an antioxidant system and ROS generation was destroyed by the surplus ROS produced by $\mathrm{Cr}(\mathrm{VI})$, then leading to DNA damage.

Hyaluronic acid, because of its unique molecular structure and physicochemical properties, plays important physiological functions in the body, such as lubricating joints, regulating vascular wall permeability, regulating the diffusion and transport of proteins and electrolytes, and promoting wound healing. There have been literatures reported that a preincubation of HMW-HA could protect corneal epithelial cells against oxidative damage induced by ultraviolet $\mathrm{B}[24,25]$, benzalkonium chloride [22, 40], EDTA [41], sodium lauryl sulfate [26], and so on. In the present study, we confirmed the protective role of $0.2 \%$ $1000 \mathrm{kDa}$ HA against genotoxicity of $\mathrm{Cr}(\mathrm{VI})$ on HCE cells. HA preincubation effectively enhanced the relative cell survival rates and reduced the DNA damage and ROS generation induced by $\mathrm{Cr}(\mathrm{VI})$ in $\mathrm{HCE}$ cells. It could be explained that HA may serve as a scavenger of free radicals and as an antioxidant, which can potentially absorb ROS [22]. Moreover, it was considered that HA could specifically bind to some cell surface receptors, such as CD44 receptor, which has been proved to be expressed on human epithelial cells [22]. Their study suggested that HA could protect cell membranes by interacting with the CD44 receptor. We thought that the CD44 receptor could be a key to understanding how HMW-HA protects $\mathrm{HCE}$ cells from genotoxicity of $\mathrm{Cr}(\mathrm{VI})$, and we would like to consider such research.

In conclusion, our present study showed that $\mathrm{Cr}(\mathrm{VI})$ could increase ROS formation and cause DNA strand breaks in HCE cells. In addition, $1000 \mathrm{kDa}$ HA significantly reduces all the $\mathrm{Cr}(\mathrm{VI})$-induced cytotoxic effects we observed. A study [22] suggested that $1000 \mathrm{kDa}$ HA could form a cytoprotective coat on the cell membrane and thus prevents BAK cytotoxicity. HA $(1000 \mathrm{kDa})$ may be a potential therapeutic agent to corneal injuries caused by $\mathrm{Cr}(\mathrm{VI})$ and other toxic agents. However, in vitro studies may not reflect the real situations in vivo, so further in vivo studies are needed to extrapolate these in vitro findings to clinical applications.

\section{Conflicts of Interest}

The authors have no conflict of interest. 


\section{Acknowledgments}

This work was supported by grants from the Public Welfare Technology Project of Science Technology Department of Zhejiang Province (2015C33115; Hangzhou, Zhejiang, China), National Natural Science Foundation of China (81472960, 81001242, and 81502794) Zhejiang Provincial Natural Science (LY13H260002), Zhejiang Provincial Program for the Cultivation of High-Level Innovative Health Talents (2014), and Zhejiang Committee of Science and Technology (2014F10G, 2015F10013).

\section{References}

[1] K. K. Das, S. A. Dhundasi, and S. N. Das, "Hexavalent chromium and its effect on health: possible protective role of garlic (Allium sativum Linn)," Journal of Basic and Clinical Physiology and Pharmacology, vol. 22, no. 1-2, pp. 3-10, 2011.

[2] H. Lieberman, "Chrome ulcerations of the nose and throat," The New England Journal of Medicine, vol. 225, no. 4, pp. 132-133, 1941.

[3] J. B. Meyers, "Acute pulmonary complications following inhalation of chromic acid mist," A.M.A. Archives of Industrial Hygiene and Occupational Medicine, vol. 2, no. 6, pp. 742747, 1950.

[4] H. S. Novey, M. Habib, and I. D. Wells, "Asthma and IgE antibodies induced by chromium and nickel salts," The Journal of Allergy and Clinical Immunology, vol. 72, no. 4, pp. 407-412, 1983.

[5] J. M. Olaguibel and A. Basomba, "Occupational asthma induced by chromium salts," Allergologia et Immunopathologia, vol. 17, no. 3, pp. 133-136, 1989.

[6] H. Li, "Treatment of ocular trauma induced by sodium dichromate," Chinese Journal of Ocular Trauma and Occupational Eye Disease, vol. 27, no. 9, pp. 697-698, 2005.

[7] L. L. Bingguang Liao and D. Zhao, "Sodium bichromate eye burn in the integrative medicine," Clinical Journal of Chinese Medicine, vol. 2, no. 20, pp. 80-81, 2010.

[8] R. Franco, O. Schoneveld, A. G. Georgakilas, and M. I. Panayiotidis, "Oxidative stress, DNA methylation and carcinogenesis," Cancer Letters, vol. 266, no. 1, pp. 6-11, 2008.

[9] J. C. Lee, Y. O. Son, P. Pratheeshkumar, and X. Shi, "Oxidative stress and metal carcinogenesis," Free Radical Biology \& Medicine, vol. 53, no. 4, pp. 742-757, 2012.

[10] K. Salnikow and A. Zhitkovich, "Genetic and epigenetic mechanisms in metal carcinogenesis and cocarcinogenesis: nickel, arsenic, and chromium," Chemical Research in Toxicology, vol. 21, no. 1, pp. 28-44, 2008.

[11] R. M. Sedman, J. Beaumont, T. A. McDonald, S. Reynolds, G. Krowech, and R. Howd, "Review of the evidence regarding the carcinogenicity of hexavalent chromium in drinking water," Journal of Environmental Science and Health. Part C, Environmental Carcinogenesis \& Ecotoxicology Reviews, vol. 24, no. 1, pp. 155-182, 2006.

[12] A. Chiu, X. L. Shi, W. K. Lee et al., "Review of chromium (VI) apoptosis, cell-cycle-arrest, and carcinogenesis," Journal of Environmental Science and Health. Part C, Environmental Carcinogenesis \& Ecotoxicology Reviews, vol. 28, no. 3, pp. 188-230, 2010.
[13] J. P. Fabisiak, G. G. Borisenko, S. X. Liu, V. A. Tyurin, B. R. Pitt, and V. E. Kagan, "Redox sensor function of metallothioneins," Methods in Enzymology, vol. 353, pp. 268-281, 2002.

[14] A. Galanis, A. Karapetsas, and R. Sandaltzopoulos, "Metalinduced carcinogenesis, oxidative stress and hypoxia signalling," Mutation Research, vol. 674, no. 1-2, pp. 31-35, 2009.

[15] D. Ziech, R. Franco, A. Pappa, and M. I. Panayiotidis, "Reactive oxygen species (ROS)-induced genetic and epigenetic alterations in human carcinogenesis," Mutation Research, vol. 711, no. 1-2, pp. 167-173, 2011.

[16] K. Jomova and M. Valko, "Advances in metal-induced oxidative stress and human disease," Toxicology, vol. 283, no. 2-3, pp. 65-87, 2011.

[17] S. N. Asmatullah and A. R. Shakoori, "Embryotoxic and teratogenic effects of hexavalent chromium in developing chicks of Gallus domesticus," Bulletin of Environmental Contamination and Toxicology, vol. 61, no. 3, pp. 281-288, 1998.

[18] W. Apel, D. Stark, A. Stark, S. O'Hagan, and J. Ling, "Cobalt-chromium toxic retinopathy case study," Documenta Ophthalmologica, vol. 126, no. 1, pp. 69-78, 2013.

[19] B. Weissman and K. Meyer, "The structure of hyalobiuronic acid and of hyaluronic acid from umbilical cord," Journal of the American Chemical Society, vol. 76, no. 7, pp. 1753-1757, 1954.

[20] M. E. Johnson, P. J. Murphy, and M. Boulton, "Effectiveness of sodium hyaluronate eyedrops in the treatment of dry eye," Graefe's Archive for Clinical and Experimental Ophthalmology, vol. 244, no. 1, pp. 109-112, 2006.

[21] W. Y. Chen and G. Abatangelo, "Functions of hyaluronan in wound repair," Wound Repair and Regeneration, vol. 7, no. 2, pp. 79-89, 1999.

[22] T. Pauloin, M. Dutot, J. M. Warnet, and P. Rat, "In vitro modulation of preservative toxicity: high molecular weight hyaluronan decreases apoptosis and oxidative stress induced by benzalkonium chloride," European Journal of Pharmaceutical Sciences, vol. 34, no. 4-5, pp. 263-273, 2008.

[23] G. M. Campo, A. Avenoso, S. Campo et al., "NF-kB and caspases are involved in the hyaluronan and chondroitin-4-sulphate-exerted antioxidant effect in fibroblast cultures exposed to oxidative stress," Journal of Applied Toxicology, vol. 28, no. 4, pp. 509-517, 2008.

[24] T. Pauloin, M. Dutot, F. Joly, J. M. Warnet, and P. Rat, "High molecular weight hyaluronan decreases UVB-induced apoptosis and inflammation in human epithelial corneal cells," Molecular Vision, vol. 15, pp. 577-583, 2009.

[25] J. M. Li, H. C. Chou, S. H. Wang et al., "Hyaluronic aciddependent protection against UVB-damaged human corneal cells," Environmental and Molecular Mutagenesis, vol. 54, no. 6, pp. 429-449, 2013.

[26] T. Pauloin, M. Dutot, H. Liang, E. Chavinier, J. M. Warnet, and P. Rat, "Corneal protection with high-molecular-weight hyaluronan against in vitro and in vivo sodium lauryl sulfate-induced toxic effects," Cornea, vol. 28, no. 9, pp. 1032-1041, 2009.

[27] J. Lou, G. Chu, G. Zhou et al., "Comparison between two kinds of cigarette smoke condensates (CSCs) of the cytogenotoxicity and protein expression in a human B-cell lymphoblastoid cell line using CCK-8 assay, comet assay and protein microarray," Mutation Research, vol. 697, no. 1-2, pp. 55-59, 2010.

[28] N. P. Singh, M. T. McCoy, R. R. Tice, and E. L. Schneider, "A simple technique for quantitation of low levels of DNA damage in individual cells," Experimental Cell Research, vol. 175, no. 1, pp. 184-191, 1988. 
[29] A. R. Collins, A. A. Oscoz, G. Brunborg et al., "The comet assay: topical issues," Mutagenesis, vol. 23, no. 3, pp. 143151, 2008.

[30] M. Zhang, X. Li, Y. Lu et al., "Studying the genotoxic effects induced by two kinds of bentonite particles on human B lymphoblast cells in vitro," Mutation Research, vol. 720, no. 1-2, pp. 62-66, 2011.

[31] K. P. Nickens, S. R. Patierno, and S. Ceryak, "Chromium genotoxicity: a double-edged sword," Chemico-Biological Interactions, vol. 188, no. 2, pp. 276-288, 2010.

[32] R. D. Snyder, "Role of active oxygen species in metal-induced DNA strand breakage in human diploid fibroblasts," Mutation Research, vol. 193, pp. 237-246, 1988.

[33] T. P. Wakeman, W. J. Kim, S. Callens, A. Chiu, K. D. Brown, and $\mathrm{B} . \mathrm{Xu}$, "The ATM-SMC1 pathway is essential for activation of the chromium[VI]-induced S-phase checkpoint," Mutation Research, vol. 554, no. 1-2, pp. 241-251, 2004.

[34] S. S. Wise, A. L. Holmes, Q. Qin et al., "Comparative genotoxicity and cytotoxicity of four hexavalent chromium compounds in human bronchial cells," Chemical Research in Toxicology, vol. 23, no. 2, pp. 365-372, 2010.

[35] A. K. Patlolla, C. Barnes, D. Hackett, and P. B. Tchounwou, "Potassium dichromate induced cytotoxicity, genotoxicity and oxidative stress in human liver carcinoma (HepG2) cells," International Journal of Environmental Research and Public Health, vol. 6, no. 2, pp. 643-653, 2009.

[36] J. Lou, L. Jin, N. Wu et al., "DNA damage and oxidative stress in human B lymphoblastoid cells after combined exposure to hexavalent chromium and nickel compounds," Food and Chemical Toxicology, vol. 55, pp. 533-540, 2013.

[37] Y. H. Lee, S. B. Su, C. C. Huang et al., "N-acetylcysteine attenuates hexavalent chromium-induced hypersensitivity through inhibition of cell death, ROS-related signaling and cytokine expression," PloS One, vol. 9, no. 9, article e108317, 2014.

[38] L. Bergendi, L. Benes, Z. Durackova, and M. Ferencik, "Chemistry, physiology and pathology of free radicals," Life Sciences, vol. 65, no. 18-19, pp. 1865-1874, 1999.

[39] S. R. Atilano, M. Chwa, D. W. Kim et al., "Hydrogen peroxide causes mitochondrial DNA damage in corneal epithelial cells," Cornea, vol. 28, no. 4, pp. 426-433, 2009.

[40] H. Wu, H. Zhang, C. Wang et al., "Genoprotective effect of hyaluronic acid against benzalkonium chloride-induced DNA damage in human corneal epithelial cells," Molecular Vision, vol. 17, pp. 3364-3370, 2011.

[41] J. Ye, H. Wu, Y. Wu et al., "High molecular weight hyaluronan decreases oxidative DNA damage induced by EDTA in human corneal epithelial cells," Eye (London, England), vol. 26, no. 7, pp. 1012-1020, 2012. 


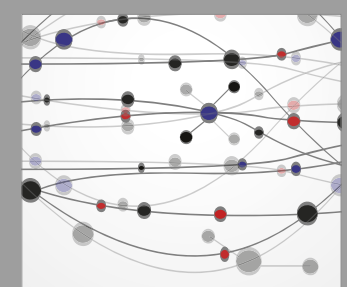

The Scientific World Journal
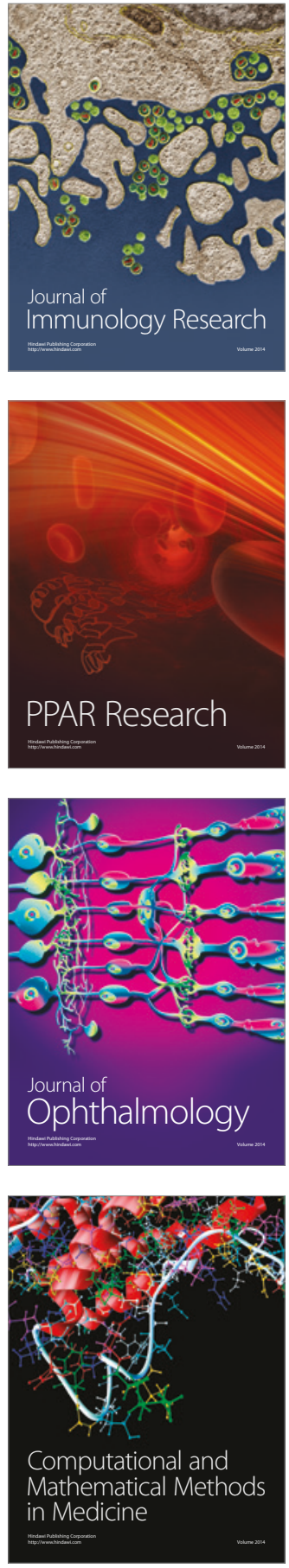

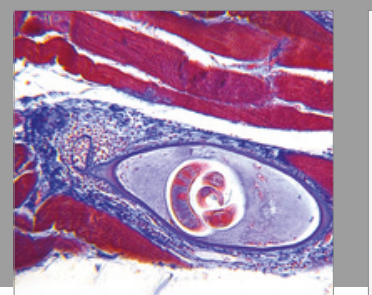

Gastroenterology Research and Practice
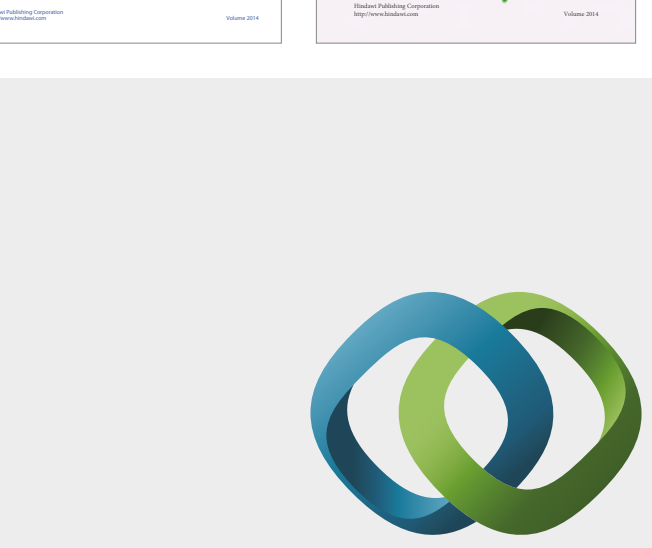

\section{Hindawi}

Submit your manuscripts at

https://www.hindawi.com
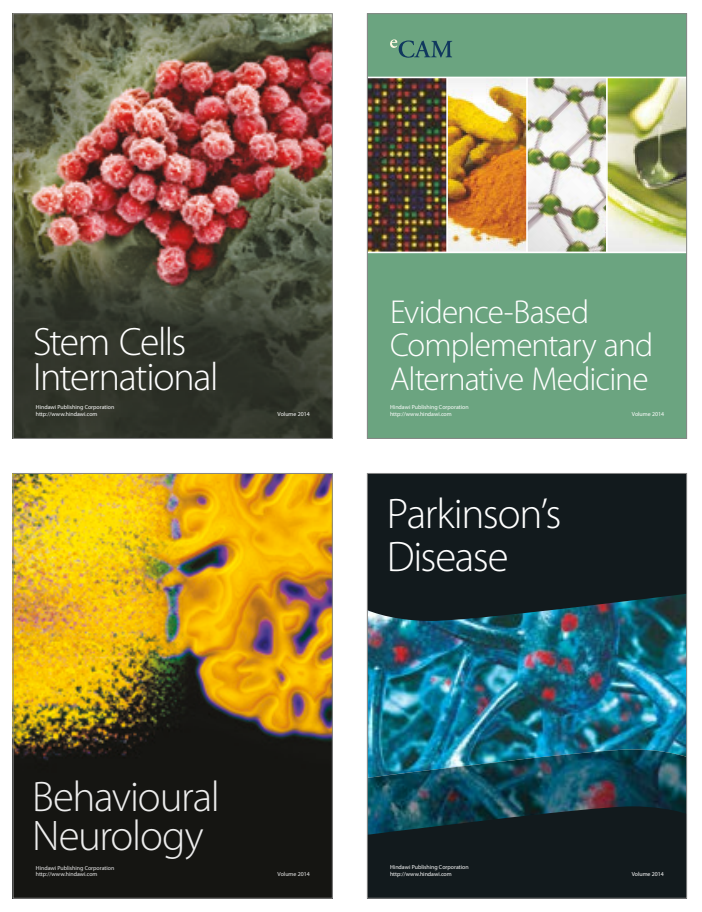
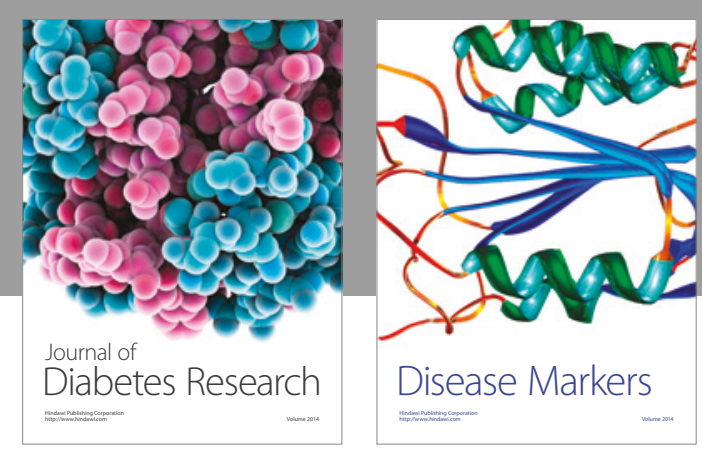

Disease Markers
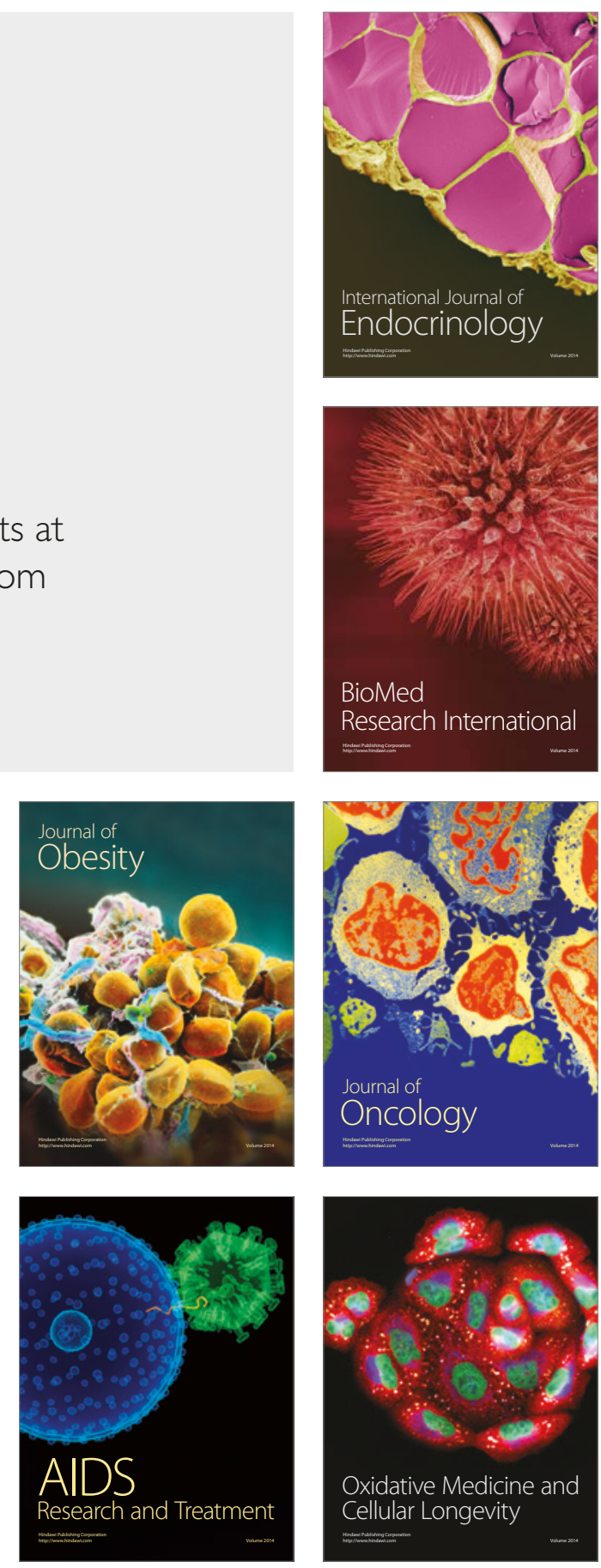